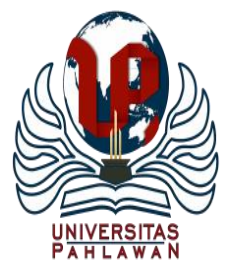

Edukatif : Jurnal Ilmu Pendidikan Volume 3 Nomor 4 Tahun 2021 Halm 1152 - 1160

EDUKATIF: JURNAL ILMU PENDIDIKAN

Research \& Learning in Education

https://edukatif.org/index.php/edukatif/index

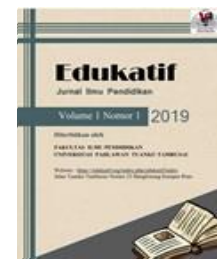

\title{
Analisis Kesulitan Siswa Dalam Pelaksanaan Pembelajaran Bahasa Jerman Secara Daring Selama Pandemi Covid-19 Di Sekolah Menengah Atas
}

\author{
Usfathon Fathonah $^{1 凶}$, Herri Akhmad Bukhori ${ }^{2}$ \\ Universitas Negeri Malang, Indonesia ${ }^{1,2}$ \\ E-mail : usfathonf@gmail.com ${ }^{1}$, herri.akhmad.fs@um.ac.id ${ }^{2}$
}

\begin{abstract}
Abstrak
Penelitian ini bertujuan untuk mendeskripsikan faktor-faktor yang menyebabkan siswa kesulitan selama pembelajaran bahasa Jerman secara daring serta cara mengatasi kesulitan tersebut. Jenis penelitian ini adalah kualitatif deskriptif dengan mendeskripsikan data yang diperoleh dari angket dan wawancara. Subjek dalam penelitian ini adalah 35 siswa kelas XI IPS 1 dan XI Bahasa SMAN 6 Malang. Hasil penelitian menunjukkan bahwa faktor-faktor yang menyebabkan siswa kesulitan adalah (1) koneksi internet yang tidak stabil, (2) keterbatasan kuota, (3) suasana rumah yang tidak kondusif, (4) siswa kesulitan memahami materi yang diajarkan secara daring, (5) media pembelajaran kurang variatif, dan (6) siswa kesulitan dalam membagi waktu belajar. Cara siswa mengatasi kesulitan tersebut adalah dengan memanfaatkan sumber-sumber belajar yang tersedia di internet, bertanya kepada guru dan teman, serta berusaha menemukan solusi secara mandiri seperti mencari tempat yang tenang untuk mengikuti pembelajaran secara daring dan meminta tethering kepada orang tua atau keluarga. Kesimpulan dari penelitian ini adalah terdapat berbagai faktor kesulitan yang dialami siswa selama pelaksanaan pembelajaran bahasa Jerman secara daring, baik dari faktor internal maupun faktor eksternal. Siswa telah berusaha mengatasi kesulitan-kesulitan tersebut dan diharapkan hasil penelitian ini dapat dijadikan acuan untuk meningkatkan efektivitas dari pembelajaran daring kedepannya.
\end{abstract}

Kata Kunci: kesulitan siswa, pembelajaran daring, bahasa Jerman, COVID-19.

\section{Abstract}

This study aims to describe the factors that cause students difficulties during learning German by online and how to overcome these difficulties. This type of research is descriptive qualitative by describing the data obtained from questionnaires and interviews. The subjects in this study were 35 students of 11 Social 1 class and 11 Language class of 6 Senior High School, Malang. The results showed that the factors that caused students difficulties were (1) an unstable internet connection, (2) limited quota, (3) the atmosphere of the house is not conducive, (4) students had difficulty understanding the teaching material by online, (5) learning media is less varied, and (6) students had difficulty in dividing learning time. The way students overcome these difficulties is by utilizing learning resources available on the internet, asking teachers and friends, and trying to find solutions independently such as finding a quiet place to participate in learning by online and asking for tethering mobile hotspot to parents or family. The conclusion of this study is that there are various difficulty factors experienced by studentsduring the implementation of German language learning online, both from internal and external factors. Students have tried to overcome these difficultiesand is it hoped that the resultsof this study can be used as a reference to improve the effectivenessof online learning in the future.

Keywords: student difficulties, online learning, German language, COVID-19.

Copyright (c) 2021 Usfathon Fathonah, Herri Akhmad Bukhori

$\triangle$ Corresponding author

Email : usfathonf@gmail.com

DOI : https://doi.org/10.31004/edukatif.v3i4.493

ISSN 2656-8063 (Media Cetak)

ISSN 2656-8071 (Media Online)

Edukatif : Jurnal Ilmu Pendidikan Vol 3 No 4 Tahun 2021 p-ISSN 2656-8063 e-ISSN 2656-8071 


\section{Analisis Kesulitan Siswa Dalam Pelaksanaan Pembelajaran Bahasa Jerman Secara Daring Selama Pandemi Covid-19 di Sekolah Menengah Atas-Usfathon Fathonah, Herri Akhmad Bukhori DOI : https://doi.org/10.31004/edukatif.v3i4.493}

\section{PENDAHULUAN}

COVID-19 merupakan pandemi yang sedang ramai diperbincangkan di seluruh dunia hingga membuat dunia menjadi resah. Pemerintah Republik Indonesia telah melakukan beberapa upaya untuk memutus rantai penyebaran COVID-19, seperti melakukan Pembatasan Sosial Berskala Besar (PSBB) atau Physical quarantine, menghentikan berbagai acara atau kegiatan lainnya yang sifatnya berkerumun untuk menghindari virus secara kontak fisik (Suni Astini, 2020). Hal tersebut tentunya berdampak pada beberapa aspek kehidupan. Salah satu dampak dari COVID-19 terhadap dunia pendidikan adalah kebijakan pemerintah yang melakukan kegiatan belajar di rumah dengan pembelajaran jarak jauh untuk seluruh pelajar di Indonesia karena adanya pembatasan sosial berskala besar (PSBB). Berkaitan dengan hal tersebut, pada tanggal 24 Maret 2020 Menteri Pendidikan dan Kebudayaan Republik Indonesia menerbitkan Surat Edaran Nomor 4 Tahun 2020 Tentang Pelaksanaan Kebijakan Pendidikan dalam Masa Darurat Penyebaran Coronavirus Disease-19 (COVID-19). Surat tersebut berisi mengenai kegiatan pembelajaran yang dilakukan secara jarak jauh atau daring guna memberikan pengalaman belajar yang bermakna dan tidak membebani siswa.

Alternatif pembelajaran yang digunakan saat masa darurat COVID-19 salah satunya adalah pembelajaran secara daring. Menurut (Isman, 2017), pembelajaran secara daring merupakan pemanfaatan jaringan internet dalam proses pembelajaran. Pelaksanaan pembelajaran daring membutuhkan kualitas jaringan internet dengan aksesibilitas, konektivitas, dan fleksibilitas yang baik guna menjalin berbagai jenis interaksi pembelajaran secara daring. Pada implementasinya, pembelajaran secara daring membutuhkan perangkat-perangkat yang mendukung serta memadai seperti Smartphone, tablet, dan laptop yang dapat digunakan untuk mengakses informasi di mana saja dan kapan saja (Gikas \& Grant, 2013). Selain itu, dibutuhkan juga platform untuk melaksanakan pembelajaran daring. Pada laman resmi Kemendikbud RI, disebutkan 12 platform atau aplikasi belajar yang dapat diakses dan digunakan dengan mudah oleh pelajar untuk belajar di rumah, yaitu (1) Meja Kita; (2) Rumah belajar; (3) Icando; (4) Indonesiax; (5) Quipper school; (6) Cisco webex; (7) Google for Education; (8) Microsoft office 365; (9) Kelas Pintar; (10) Zenius (11) Sekolahmu; (12) Ruang Guru (Handarini \& Wulandari, 2020). Menurut (Kumar \& Nanda, 2019), pembelajaran daring juga dapat dilakukan dengan menggunakan sosial media, seperti Instagram, Facebook, dan aplikasi instan yang banyak digunakan oleh masyarakat dari berbagai kalangan seperti WhatsApp.

Dalam pelaksanaan pembelajaran daring terdapat kelebihan dan kekurangan. Kelebihan tersebut seperti pembelajaran lebih praktis dan fleksibel, sebagai contoh tugas dapat diberikan oleh guru kapan saja. Selain itu, siswa dapat memperoleh informasi dengan mudah, di mana pun dan kapan pun. Orang tua juga dapat berperan aktif dengan memantau siswa selama megikuti kegiatan belajar secara daring dari rumah. Meskipun demikian, terdapat beberapa kelemahan dari pembelajaran daring. Kekurangan dari pelaksanaan pembelajaran daring adalah siswa yang tidak antusias dan tidak aktif selama kegiatan belajar mengajar serta guru tidak dapat memantau siswa secara langsung selama pembelajaran. Selain itu, beberapa faktor seperti media pembelajaran yang kurang variatif, suasana rumah yang tidak kondusif, dan kurangnya dukungan dari orang tua dapat menjadi salah satu kelemahan dari pembelajaran daring. Hal tersebut dapat berpengaruh pada motivasi dan minat siswa dalam mengikuti pembelajaran daring (Nafrin, 2021).

Observasi awal yang dilakukan oleh peneliti di salah satu sekolah di Malang menunjukkan bahwa terdapat beberapa permasalahan yang ditemui selama pelaksanaan pembelajaran bahasa Jerman secara daring. Pembelajaran pada sekolah tersebut menggunakan Google Classroom dan WhatsApp. Hasil observasi menunjukkan bahwa terdapat beberapa siswa yang tidak mengikuti kelas online, tidak melakukan presensi melalui WhatsApp, dan beberapa siswa tidak mengerjakan tugas yang diberikan oleh guru. Berdasarkan uraian permasalahan tersebut, peneliti tertarik untuk menganalisis lebih lanjut faktor-faktor apa saja yang menyebabkan siswa kesulitan selama pelaksanaan pembelajaran bahasa Jerman secara daring serta cara siswa dalam mengatasi kesulitan tersebut. 


\section{Analisis Kesulitan Siswa Dalam Pelaksanaan Pembelajaran Bahasa Jerman Secara Daring Selama Pandemi Covid-19 di Sekolah Menengah Atas-Usfathon Fathonah, Herri Akhmad Bukhori DOI : https://doi.org/10.31004/edukatif.v3i4.493}

Peneliti terdahulu terkait kesulitan dalam pembelajaran daring telah dilakukan oleh (Asmuni, 2020) dengan judul "Problematika Pembelajaran Daring di Masa Pandemi Covid-19 dan Solusi Pemecahannya".

Asmuni menemukan bahwa terdapat problematika dalam pelaksanana pembelajaran daring yang dialami guru, siswa, dan orang tua. Beberapa problematika tersebut adalah kurangnya penguasaan guru terhadap teknologi, keterbatasan elektonik dan koneksi internet yang dimiliki oleh guru dan siswa, guru tidak dapat memantau siswa secara langsung selama pembelajaran daring, dan keterbatasan orang tua untuk mendampingi siswa selama pembelajaran daring. Solusi pemecahan yang disebutkan adalah dengan meningkatkan kemampuan penguasaan teknologi, melibatkan orang tua dalam kegiatan belajar mengajar. Penelitian kedua yang serupa dilakukan oleh (Corinna et al., 2020) dengan judul " Problematika Pembelajaran Bahasa Arab Secara Daring: Studi Kasus Mahasiswa Program Studi Bahasa Dan Kebudayaan Arab Universitas AL-Azhar Indonesia". Hasil penelitian (Corinna et al., 2020) menunjukkan bahwa terdapat kendala yang dialami mahasiswa selama pelaksanakan pembelajaran daring seperti masalah pada jaringan internet. Selain itu, kendala pembelajaran dibagi menjadi empat bagian, yaitu pada kemampuan mendengar, kemampuan menulis, kemampuan berbicara, dan kemampuan membaca. Kedua penelitian di atas memiliki kesamaan dengan penelitian ini yaitu berfokus pada kesulitan yang dialami siswa dalam pelaksaan pembelajaran daring di masa pandemi COVID-19. Perbedaanya terletak pada mata pelajaran yang diteliti, yakni bahasa Jerman. Penelitian ini perlu dilakukan untuk mengetahui lebih lanjut faktor-faktor apa saja yang menyebabkan siswa kesulitan dan bagaimana siswa selama ini mengatasi kesulitan tersebut.

\section{METODE}

Penelitian ini menggunakan metode kualitatif deskriptif. Pada penelitian ini, peneliti berperan sebagai instrumen kunci dengan mengumpulkan dan menganalisis data serta melaporkan hasil penelitian. Subjek penelitian ini adalah 35 siswa dari kelas XI IPS 1 dan XI Bahasa SMAN 6 Malang. Penelitian ini dilakukan secara daring selama lima hari untuk memperoleh data. Teknik pengumpulan data yang digunakan adalah angket dan wawancara. Angket diberikan secara daring melalui Google form yang dikirimkan melalui grup WhatsApp dan wawancara juga dilakukan melalui aplikasi WhatsApp.

Prosedur pengumpulan data angket yang dilakukan peneliti adalah sebagai berikut. (1) Peneliti menyusun rancangan pernyataan untuk angket. (2) Peneliti memasukkan pernyataan yang telah disusun ke Google form. (3) Peneliti membagikan link Google form kepada siswa melalui Grup WhatsApp kelas. (4) Peneliti memeriksa hasil angket siswa. (5) Peneliti menganalisis data angket siswa.

Prosedur pengumpulan data wawancara yang dilakukan oleh peneliti adalah sebagai berikut. (1) Peneliti menyusun pertanyaan. (2) Peneliti menghubungi siswa untuk melakukan wawancara. (3) Peneliti melakukan wawancara via WhatsApp dengan siswa. (5) Peneliti membuat transkrip wawancara. (6) Peneliti menganalisis data hasil wawancara. Setelah seluruh data terkumpul, peneliti menganalisis data dengan tiga langkah, yakni menyederhanakan data, memaparkan data dan menarik kesimpulan. Pengecekan keabsahan data dilakukan oleh peneliti dengan triangulasi metode. Triangulasi metode adalah teknik pengecekan keabsahan dengan membandingkan data yang diperoleh dari dua atau lebih metode. Pada penelitian ini, peneliti membandingkan data yang diperoleh dari hasil angket dan hasil wawancara.

\section{HASIL DAN PEMBAHASAN}

Pembelajaran bahasa Jerman di SMA Negeri 6 saat ini dilakukan secara daring menggunakan platform Google Clasroom, WhatsApp,dan Zoom. Hal ini sesuai dengan yang disampaikan oleh (Handarini \& Wulandari, 2020) bahwa pembelajaran secara daring adalah pembelajaran yang dilakukan secara jarak jauh tanpa tatap muka secara langsung, melainkan dengan menggunakan platform yang dapat membantu selama 


\section{Analisis Kesulitan Siswa Dalam Pelaksanaan Pembelajaran Bahasa Jerman Secara Daring Selama Pandemi Covid-19 di Sekolah Menengah Atas-Usfathon Fathonah, Herri Akhmad Bukhori DOI : https://doi.org/10.31004/edukatif.v3i4.493}

proses pembelajaran berlangsung. Hal ini serupa dengan yang disampaikan oleh (Malyana, 2020) bahwa pembelajaran secara daring menggunakan metode belajar yang interaktif dengan memanfaatkan jaringan internet, seperti Learning Manajemen System (LMS), Google Meet, Google Classroom,Zoom, dan lain sebagainya.

Pada pembelajaran daring, terdapat beberapa faktor penyebab kesulitan dalam pembelajaran daring. Terdapat beberapa faktor yang menyebabkan siswa kesulitan selama pembelajaran bahasa Jerman berlangsung. Faktor-faktor tersebut diperoleh dari hasil angket. Hasil angket dapat dilihat pada tabel 1.

Tabel 1. Rekapitulasi Angket Siswa

\begin{tabular}{|c|c|c|c|c|c|}
\hline \multirow{2}{*}{ No. } & \multirow[t]{2}{*}{ Pernyataan } & \multicolumn{4}{|c|}{ Alternatif Jawaban } \\
\hline & & SS & $\mathrm{S}$ & $\mathrm{KS}$ & $\mathrm{TS}$ \\
\hline 1. & $\begin{array}{l}\text { Saya merasa pembelajaran secara daring } \\
\text { menyenangkan }\end{array}$ & 2 & 9 & 20 & 4 \\
\hline 2. & $\begin{array}{l}\text { Saya merasa pembelajaran secara daring mudah } \\
\text { dipahami }\end{array}$ & 1 & 3 & 24 & 7 \\
\hline 3. & $\begin{array}{l}\text { Saya mudah menerima materi pembelajaran secara } \\
\text { daring }\end{array}$ & - & 7 & 26 & 2 \\
\hline 4. & $\begin{array}{l}\text { Saya bisa berkonsentrasi penuh saat pembelajaran } \\
\text { daring }\end{array}$ & - & 13 & 19 & 3 \\
\hline 5. & Saya merasa kesulitan belajar secara daring & 6 & 18 & 9 & 2 \\
\hline 6. & $\begin{array}{l}\text { Saya merasa terbantu dengan kuota belajar yang } \\
\text { diberikan oleh pemerintah }\end{array}$ & 4 & 8 & 11 & 12 \\
\hline 7. & $\begin{array}{l}\text { Saya merasa pembelajaran daring membutuhkan } \\
\text { kuota yang banyak }\end{array}$ & 18 & 10 & 5 & 2 \\
\hline 8. & $\begin{array}{l}\text { Saya harus mengeluarkan banyak uang untuk } \\
\text { membeli kuota }\end{array}$ & 13 & 9 & 7 & 6 \\
\hline 9. & Saya tidak dapat belajar secara mandiri & 4 & 17 & 11 & 3 \\
\hline 10. & $\begin{array}{l}\text { Saya merasa suasana rumah tidak kondusif saat } \\
\text { pembelajaran daring }\end{array}$ & 9 & 9 & 7 & 10 \\
\hline 11. & $\begin{array}{l}\text { Saya dibantu orang tua saat merasa ada kesulitan } \\
\text { dalam materi belajar }\end{array}$ & 3 & 12 & 9 & 11 \\
\hline 12. & $\begin{array}{l}\text { Saya merasa bosan ketika guru menjelaskan materi } \\
\text { belajar via Google Meet }\end{array}$ & 6 & 11 & 12 & 6 \\
\hline 13. & $\begin{array}{l}\text { Saya tidak dapat menerima dengan baik materi } \\
\text { belajar yang disampaikan guru }\end{array}$ & 4 & 20 & 7 & 4 \\
\hline 14. & $\begin{array}{l}\text { Saya menguasai semua materi pembelajaran bahasa } \\
\text { jerman yang disampaikan guru secara daring }\end{array}$ & - & 8 & 20 & 7 \\
\hline 15. & $\begin{array}{l}\text { Saya tidak mempelajari ulang materi yang telah } \\
\text { disampaikan oleh guru }\end{array}$ & 1 & 13 & 21 & - \\
\hline 16. & Saya merasa tugas yang diberikan terlalu banyak & 11 & 14 & 9 & 1 \\
\hline 17. & $\begin{array}{l}\text { Saya merasa belajar di rumah lebih baik daripada } \\
\text { di sekolah }\end{array}$ & 1 & 6 & 14 & 14 \\
\hline 18. & $\begin{array}{l}\text { Saya selalu mendapat nilai di atas kkm selama } \\
\text { pembelajaran daring }\end{array}$ & 3 & 7 & 21 & 4 \\
\hline 19. & $\begin{array}{l}\text { Saya merasa media yang digunakan kurang } \\
\text { menarik }\end{array}$ & 5 & 13 & 14 & 3 \\
\hline 20. & $\begin{array}{l}\text { Saya dapat membagi waktu belajar secara daring } \\
\text { dengan baik }\end{array}$ & 3 & 6 & 20 & 6 \\
\hline
\end{tabular}

Pada tabel 1 dapat diketahui kesulitan-kesulitan siswa selama pembelajaran daring pada mata pelajaran bahasa Jerman. Bagi sebagain besar siswa, pembelajaran bahasa Jerman secara daring kurang menyenangkan. 


\section{Analisis Kesulitan Siswa Dalam Pelaksanaan Pembelajaran Bahasa Jerman Secara Daring Selama Pandemi Covid-19 di Sekolah Menengah Atas-Usfathon Fathonah, Herri Akhmad Bukhori DOI : https://doi.org/10.31004/edukatif.v3i4.493}

Hal tersebut dapat dilihat dari jawaban siswa pada penyataan ke-1, terdapat 2 siswa menyatakan sangat setuju, 9 siswa menyatakan kurang setuju, 20 siswa menyatakan kurang setuju, dan 4 siswa menyatakan tidak setuju. Selain itu, hampir seluruh siswa sependapat bahwa materi yang diberikan selama pembelajaran daring tidak mudah dipahami. Pada pernyataan ke-2, terdapat 1 siswa menyatakan sangat setuju, 3 siswa menyatakan setuju, 24 siswa menyatakan kurang setuju, dan 7 siswa menyatakan tidak setuju. Hal tersebut serupa dengan hasil penelitian yang dilakukan oleh (Turmuzi \& Dasing, 2021) bahwa penyampaian materi yang dilakukan pengajar sulit dipahami oleh siswa, 50,9\% atau 27 responden menjawab materi yang disampaikan sulit untuk dipahami.

Berkaitan dengan pernyataan sebelumnya, sebagai besar siswa juga sependapat bahwa mereka kesulitan dalam menerima materi yang diberikan secara daring. Dapat dilihat pada pernyataan ke-3, terdapat 7 siswa menyatakan sangat setuju, 26 siswa menyatakan kurang tersebut, dan 2 siswa mengatakan tidak setuju. Hal tersebut membuktikan bahwa siswa tidak dapat memahami materi pembelajaran secara daring. Penyebab siswa kesulitan dalam menerima serta memahami materi yang diberikan adalah kurangnya konsentrasi siswa selama pembelajaran daring berlangsung. Hal ini diketahui dari jawaban angket siswa pada pernyataan ke-4, terdapat 13 siswa menyatakan setuju, 19 siswa menyatakan kurang setuju, dan 2 siswa menyatakan tidak setuju. Perolehan jawaban tersebut membuktikan bahwa sebagian siswa tidak dapat berkonsentrasi penuh selama pembelajaran daring berlangsung. Temuan ini sesuai dengan yang disampaikan oleh (Zainal Arifin, 2012) bahwa indikator yang menyebabkan kesulitan belajar siswa adalah tidak dapat menguasai materi pelajaran sesuai dengan waktu yang telah ditentukan dan tidak menyesuaikan diri dengan lingkungannya. Pembelajaran daring memiliki waktu yang lebih terbatas dibandingkan pembelajaran langsung yang dilakukan di kelas. Perubahan yang terjadi dari pembelajaran tatap muka menjadi pembelajaran melalui jaringan internet tentunya menjadi tantangan bagi guru dan siswa, karena perlu beradaptasi dengan perubahan tersebut.

Selama pembelajaran bahasa Jerman secara daring, sebagain besar siswa menyatakan bahwa mereka mengalami kesulitan. Hal tersebut dibuktikan dari hasil angket siswa pada pernyataan ke-5, terdapat 6 siswa menyatakan sangat setuju, 18 siswa menyatakan setuju, 9 siswa menyatakan kurang setuju, dan 2 siswa menyatakan tidak setuju. Salah satu kesulitan yang ditemukan adalah kurangnya kuota internet yangdimiliki siswa untuk melaksanakan pembelajaran daring. Hasil angket siswa pada pernyataan ke-6 menunjukan bahwa sebagian besar siswa tidak terbantu dengan kuota belajar yang telah disediakan oleh pemerintah. Pada pernyataan ke-6, terdapat 4 siswa menyatakan sangat setuju, 8 siwa menyatakan setuju, 11 siswa menyatakan kurang setuju, dan 12 siswa menyatakan tidak setuju. Berkaitan dengan pernyataan sebelumnya, sebagian besar siswa sependapat bahwa pembelajaran daring membutuhkan kuota yang banyak. Hal ini dibuktikan dari hasil angket siswa pada pernyataan ke-7, terdapat 18 siswa menyatakan sangat setuju, 10 siswa menyatakan setuju, 5 siswa menyatakan kurang setuju, dan 2 siwa menyatakan tidak setuju. Selain itu, untuk memenuhi kebutuhan kuota tersebut, siswa banyak mengeluarkan uang. Hal tersebut dibuktikan dari hasil angket siswa pada pernyataan ke-8, terdapat 13 siswa menyatakan sangat setuju, 9 siswa menyatakan setuju, 7 siswa menyatakan kurang setuju, dan 6 siswa menyatakan tidak setuju.

Perubahan bentuk pembelajaran dari tatap muka di kelas menjadi daring merupakan hal yang baru bagi guru dan siswa. Siswa perlu melakukan pembelajaran secara mandiri dari rumah, tanpa bisa melakukan konsultasi secara langsung atau real-time bersama guru. Pada pernyataan ke-9, terdapat 4 siswa menyatakan sangat setuju, 17 siswa menyatakan setuju, 11 siswa menyatakan kurang setuju, dan 3 siswa menyatakan tidak setuju. Hasil angket siswa tersebut menunjukkan bahwa sebagian siswa tidak dapat belajar secara mandiri di rumah selama pembelajaran daring dan sebagian siswa lainnya sudah dapat menyesuaikan diri serta melaksanakan pembelajaran secara mandiri.

Kesulitan yang dialami siswa selama pembelajaran daring, tidak hanya disebabkan dari faktor internal siswa saja, melainkan juga dari faktor eksternal. Salah satu faktor eksternal yang menyebabkan siswa kesulitan adalah susasana rumah yang tidak kondusif. Pada hasil angket, pernyataan ke 10, terdapat 9 siswa 


\section{Analisis Kesulitan Siswa Dalam Pelaksanaan Pembelajaran Bahasa Jerman Secara Daring Selama Pandemi Covid-19 di Sekolah Menengah Atas-Usfathon Fathonah, Herri Akhmad Bukhori DOI : https://doi.org/10.31004/edukatif.v3i4.493}

meyatakan sangat setuju, 9 siswa menyatakan setuju, 7 siswa menyatakan kurang setuju, dan 10 siswa menyatakan tidak setuju. Hal tersebut menunjukkan bahwa sebagian besar siswa merasa suasana rumah tidak kondusif selama pembelajaran daring berlangsung, sedangkan sebagain siswa lainnya merasa suasana rumah kondusif saat pembelajaran daring. Selain suasana rumah, faktor eksternal yang juga berperan selama pembelajaran daring adalah orang tua. Selama pembelajaran daring berlangsung tentunya siswa mendapati kesulitan dalam memahami materi belajar. Pada pernyataan ke-11, terdapat 3 siswa menyatakan sangat setuju, 12 siswa menyatakan setuju, 9 siswa menyatakan kurang setuju, dan 11 siswa menyatakan tidak setuju. Berdasarkan hasil tersebut, dapat diketahui bahwa sebagian besar siswa dibantu oleh orang tua ketika memiliki kesulitan dalam mempelajari materi yang diberikan selama pembelajaran daring.

Media pembelajaran yang digunakan guru saat ini adalah Google Meet. Guru menggunakan media tersebut untuk menyampaikan materi pembelajaran. Pada pernyataan ke -12 , terdapat 4 siswa menyatakan sangat setuju, 20 siswa menyatakan setuju, 7 siswa menyatakan kurang setuju, dan 7 siswa menyatakan tidak setuju. Hal ini menunjukkan bahwa sebagian besar siswa merasa bosan ketika guru menjelaskan materi belajar bahasa Jerman secara daring. Oleh karena itu, diperlukan variasi media pembelajaran oleh guru dalam menyampaikan materi untuk meningkatkan ketertarikan serta minat siswa dalam mengikuti pembelajaran. Berkaitan dengan materi pembelajaran yang diberikan secara daring, sebagian besar siswa sependapat bahwa mereka tidak dapat menerima dengan baik materi belajar bahasa Jerman yang disampaikan oleh guru. Hal ini dibuktikan dari hasil angket siswa pada pernyataan ke-13, terdapat 4 siswa menyatakan sangat setuju, 20 siswa menyatakan setuju, 7 siswa menyatakan kurang setuju, dan 4 siswa menyatakan tidak setuju. Berkaitan dengan temuan sebelumnya, hasil angket siswa pada pernyataan ke-14 menunjukkan hal serupa. Pada pernyataan ke-14, terdapat 8 siswa menyatakan setuju, 20 siswa menyatakan kurang setuju, dan 7 siswa menyatakan tidak setuju. Berdasarkan jawaban tersebut, dapat disimpulkan bahwa sebagian besar siswa tidak menguasai semua materi pembelajaran bahasa Jerman yang disampaikan guru secara daring. Salah satu yang menyebabkan siswa kesulitan dalam menguasai materi yang disampaikan adalah ketika siswa tidak mempelajari ulang materi yang telah disampaikan oleh guru selama pembelajaran daring. Pada pernyataan ke15, terdapat 1 siswa menyatakan sangat setuju, 12 siswa menyatakan setuju, 21 siswa menyatakan kurang setuju. Perolehan jawaban tersebut mengindikasikan bahwa sebagian besar siswa telah mempelajari ulang materi bahasa Jerman yang disampaikan oleh guru dan sebagain siswa lainnya tidak mempelajari ulang materi yang diberikan.

Berkaitan dengan penugasan yang diberikan oleh guru selama pembelajaran bahasa Jerman secara daring, sebagian besar siswa sependapat jika tugas yang diberikan terlalu banyak. Hal ini diketahui dari hasil angket pada pernyataan ke-16, terdapat 11 siswa menyatakan sangat setuju, 14 siswa menyatakan setuju, 9 siswa menyatakan kurang setuju, dan 1 siswa menyatakan tidak setuju. Jawaban tersebut menunjukkan bahwa sebagain besar siswa merasa tugas yang diberikan selama pembelajaran daring terlalu banyak.

Pembelajaran daring yang dilakukan dari rumah tentunya merupakan hal yang baru bagi siswa. Pada pernyataan ke-17, terdapat 1 siswa menyatakan sangat setuju, 6 siswa menyatakan setuju, 14 siswa menyatakan kurang setuju, dan 14 siswa menyatakan tidak setuju. Berdasarkan jawaban tersebut, dapat disimpulkan bahwa sebagian besar siswa berpendapat bahwa belajar di sekolah lebih baik dari pada belajar di rumah. Hal ini merupakan salah satu penyebab siswa kesulitan dalam mengikuti pembelajaran daring, karena siswa tidak nyaman melaksanakan pembelajaran dari rumah.

Perolehan nilai selama pembelajaran daring tentunya berubah, tidak sama seperti saat pembelajaran dilakukan secara tatap muka. Nilai yang didapatkan siswa selama pembelajaran daring selalu di atas kkm. Pada pernyataan ke-18, terdapat 3 siswa menyatakan sangat setuju, 13 siswa menyatakan setuju, 14 siswa menyatakan kurang setuju, dan 3 siswa menyatakan tidak setuju. Jawaban tersebut menunjukkan bahwa sebagian besar siswa tidak selalu mendapatkan nilai di atas $\mathrm{kkm}$ dan sebagian siswa lainnya selalu mendapat nilai di atas kkm selama pembelajaran bahasa Jerman secara daring. 


\section{Analisis Kesulitan Siswa Dalam Pelaksanaan Pembelajaran Bahasa Jerman Secara Daring Selama Pandemi Covid-19 di Sekolah Menengah Atas-Usfathon Fathonah, Herri Akhmad Bukhori DOI : https://doi.org/10.31004/edukatif.v3i4.493}

Dalam pembelajaran daring, peran media pembelajaran sangat penting. Media pembelajaran yang digunakan selama pembelajaran daring dapat berpengaruh terhadap kegiatan pelaksanaan pembelajaran tersebut. Pada pernyataan ke-19, terdapat 5 siswa menyatakan sangat setuju, 13 siswa menyatakan setuju, 14 siswa menyatakan kurang setuju, dan 3 siswa menyatakan tidak setuju. Hal tersebut menunjukkan bahwa sebagian siswa berpendapat media pembelajaran bahasa Jerman yang digunakan guru selama pembelajaran daring kurang menarik dan sebagian siswa lainnya berpendapat bahwa media pembelajaran yang digunakan sudah menarik.

Pengelolaan waktu belajar selama pembelajaran daring ini merupaka hal yang penting. Mengingat bahwa siswa melaksanakan pembelajaran secara mandiri dari rumah, siswa harus dapat membagi waktu belajar bahasa Jerman secara daring dengan baik. Pada pernyataan ke-20, terdapat 3 siswa menyatakan kurang setuju, 6 siswa menyatakan setuju, 20 siswa menyatakan kurang setuju, dan 6 siswa menyatakan tidak setuju. Berdasarkan jawaban tersebut dapat disimpulkan bahwa sebagian besar siswa tidak dapat membagi waktu belajar bahasa Jerman secara daring. Hal tersebut sesuai dengan penelitian yang dilakukan oleh (Cahyani et al., 2020) bahwa $61,1 \%$ siswa menyatakan tidak dapat menemukan waktu yang tepat untuk belajar di rumah karena berbagai faktor yang mempengaruhinya, seperti suasana rumah yang tidak kondusif sehingga siswa tidak dapat fokus dalam belajar dan sulit mendapatkan tempat yang tenang.

Beberapa temuan yang telah dipaparkan di atas, selaras dengan yang dikemukakan oleh (Dalyono, 2015) bahwa faktor-faktor yang menyebabkan kesulitan belajar siswa berasal dari faktor internal dan eksternal. Faktor internal disebakan dari faktor fisik yang kurang sehat atau cacat tubuh dan faktor rohani seperti bakat, minat, motivasi, kesehatan mental, dan tipe-tipe belajar siswa, sedangkan faktor eksternal berasal dari faktor keluarga seperti suasana rumah yang gaduh, kurangnya hubungan orang tua dan anak, faktor sekolah seperti hubungan guru dan murid yang kurang harmonis, metode belajar yang kurang menarik, dan kurangnya variasi media pembelajaran yang digunakan, serta faktor dari lingkungan sosial seperti teman bergaul, lingkungan tetangga, dan aktivitas dalam masyarakat. Temuan ini juga selaras dengan hasil penelitian yang dilakukan oleh (Annur, 2020), yakni terdapat beberapa kesulitan yang ditemukan selama pelaksanaan pembelajaran daring seperti, kesulitan secara teknis, sulit beradaptasi dengan pembelajaran daring, dan kurangnya kesiapan pengajar dalam pelaksanaan pembelajaran secara daring.

Seperti yang telah dikemukakan (Dalyono, 2015) kesulitan belajar yang dialami masing-masing siswa dilatarbelakangi oleh berbagai faktor. Oleh karena itu, diperlukan cara yang tepat untuk mengatasi masalah tersebut. (Aunurrahman, 2012) menyebutkan langkah-langkah penanganan tersebut sebagai berikut. (1) Perlunya identifikasi untuk memperoleh informasi dari siswa yang mengalami kesulitan belajar, (2) mendiagnosis atau meneliti sebab-sebab, sifat-sifat, dan jenis-jenis kesulitan yang dialami siswa, (3) menyiapkan rencana atau program untuk mengatasi kesulitan siswa, dan (4) terapi atau pemberian bantuan guna membantu siswa yang mengalami kesulitan.

Untuk mengatasi kesulitan siswa, (Mulyadi, 2010) menyatakan bahwa perlu dilakukan wawancara dengan siswa untuk mengetahui kendala yang dialami. Pada penelitian ini, peneliti telah melakukan wawancara dan mengidentifikasi kesulitan-kesulitan beserta dengan faktor penyebabnya. Berdasarkan hasil wawancara dengan siswa, ditemukan beberapa kendala yang dialaminya seperti terbatasnya kuota dan koneksi internet yang buruk ketika pembelajaran berlangsung, sehingga siswa sulit memahami materi yang diberikan guru selama pembelajaran daring. Berikut merupakan hasil wawancara dengan siswa berdasarkan pernyataanya:

1. Apa saja penyebab kesulitan yang anda alami selama pembelajaran bahsa Jerman secara daring?

AP: "Kendala yang saya alami ketika pembelajaran daring seperti susah sinyal lalu kondisi rumah ramai karena dekat dengan jalan raya lalu saya masih belum paham untuk pengucapan kata dalam bahasa Jerman". 
1159 Analisis Kesulitan Siswa Dalam Pelaksanaan Pembelajaran Bahasa Jerman Secara Daring Selama

Pandemi Covid-19 di Sekolah Menengah Atas-Usfathon Fathonah, Herri Akhmad Bukhori

DOI : https://doi.org/10.31004/edukatif.v3i4.493

FP: "Kesulitan yang saya alami itu terjadi ketika kuota yang tidak mencukupi, bisanya harus hotspot atau tethering dan itu menyebabkan koneksinya buruk sehingga pembelajaran sangat sulit untuk dipahami".

VA: "Kalau lagi tidak ada kuota atau WiFi di rumah mati, biasanya ketinggalan absen sama pelajaran dan kurang bisa memahami materi-materi yang dikasih sama guru".

AZ: "Dari beberapa materi itu kan ada yang sulit jadi kalo gak tatap muka itu jadi gak maksimal"

2. Bagaimana anda mengatasi kesulitan belajar bahasa Jerman secara daring?

AZ: "Saya menggunakan Google dan Brainly".

VA: "Saya membuka lagi materi yang diberikan guru untuk memahaminya lagi. Kadang saya ke rumah teman yang ada WiFi. Kalau tidak biasanya saya tethering orang di rumah yang ada kuotanya".

FP: "Untuk menghadapi kesulitan saat daring jika kuota saya habis maka maka saya meminta uang kepada orang tua saya untuk membeli kuota dan pada saat terjadi koneksi buruk dan jika saya tidak paham maka saya bertanya kepada teman saya".

AP: "Saya pergi ke rumah saudara atau ke rumah guru les unutk mendapatkan sinyal sinyal kadang juga menggunakan WiFi lalu apabila saya belum paham membuka Google Translate dan mendengarkan suara dari Google Translate.

Berdasarkan paparan hasil wawancara di atas, dapat diketahui bahwa kesulitan-kesulitan yang dialami siswa sejalan dengan hasil angket yang telah diperoleh. Terdapat beberapa cara yang dilakukan siswa untuk mengatasi kesulitan yang dialami selama pembelajaran daring tersebut. Selama ini, siswa mengatasi kesulitankesulitan tersebut dengan memanfaatkan sumber-sumber belajar yang tersedia di internet, seperti Brainly dan Google. Menurut siswa, pemanfaatan sumber-sumber belajar tersebut membantu siswa dalam memahami materi yang diberikan oleh guru. Siswa juga bertanya kepada guru atau teman apabila masih tidak memahami materi dengan baik. Selain itu, cara siswa mengatasi kesulitan dalam memahami materi yang diajarkan secara daring adalah dengan menggunakan Google Translate untuk menerjemahkan dan mendengarkan pelafalan bahasa Jerman yang benar serta mempelajari kembali materi yang diberikan oleh guru dalam bentuk word atau $p d f$. Untuk mengatasi kesulitan terkait jaringan internet, siswa mengunjungi rumah saudara untuk mendapatkan koneksi internet yang lebih baik. Temuan ini sejalan dengan hasil penelitian yang telah dilakukan oleh (Asmuni, 2020), yakni salah satu solusi yang dapat diberikan bagi siswa terhadap kendala koneksi internet adalah meminta tethering kepada kerabat atau keluarga.

Temuan pada penelitian ini hanya terbatas pada kesulitan belajar yang dialami siswa selama pelaksanaan mata pelajaran Bahasa Jerman secara daring pada masa pandemi COVID-19. Berkaitan dengan adanya penelitian ini berharap bisa meningkatkan kualiatas pembelajaran secara daring dari berbagai pihak baik dari siswa maupun guru agar dapat meningkatkan kemampuan dalam mengoperasikan teknnologi.

\section{KESIMPULAN}

Berdasarkan hasil penelitian yang telah dilakukan, dapat disimpulkan bahwa kesulitan-kesulitan siswa selama pembelajaran bahasa Jerman secara daring disebabkan oleh beberapa faktor, seperti: (1) Siswa belum beradaptasi dengan pembelajaran daring sehingga kesulitan dalam memahami materi yang diberikan, membagi waktu belajar, dan tidak dapat berkonsentrasi selama pembelajaran daring. (2) Kendala teknis berkaitan dengan jaringan internet dan keterbatasan kuota. (3) Lingkungan belajar yang tidak mendukung, dan (4) kurangnya variasi media pembelajaran yang digunakan. Untuk mengatasi kesulitan-kesulitan tersebut diperlukan dukungan dari diri sendiri dan lingkungan sekitar siswa. Siswa mengatasi kesulitan yang dialami dengan memanfaatkan sumber-sumber belajar di internet, mempelajari kembali materi serta bertanya kepada guru dan teman terkait materi pembelajaran. Selain itu, terkait kendala koneksi internet yang dialami, siswa 
1160 Analisis Kesulitan Siswa Dalam Pelaksanaan Pembelajaran Bahasa Jerman Secara Daring Selama Pandemi Covid-19 di Sekolah Menengah Atas-Usfathon Fathonah, Herri Akhmad Bukhori DOI : https://doi.org/10.31004/edukatif.v3i4.493

berusaha mencari solusi seperti meminta tethering internet kepada orang tua atau mengunjungi kerabat terdekat yang memiliki koneksi internet yang stabil.

\section{DAFTAR PUSTAKA}

Annur, M. F. (2020). Analisis Kesulitan Mahasiswa Pendidikan Matematika Dalam Pembelajaran Daring Pada Masa Pandemi Covid-19. Jurnal Kajian, Pnelitian Dan Pengembangan Kependidikan.

Asmuni, A. (2020). Problematika Pembelajaran Daring di Masa Pandemi Covid-19 dan Solusi Pemecahannya. Jurnal Paedagogy, 7(4), 281. https://doi.org/10.33394/jp.v7i4.2941

Aunurrahman. (2012). Belajar dan Pembelajaran. Alfabeta.

Cahyani, A., Listiana, I. D., \& Larasati, S. P. D. (2020). Motivasi Belajar Siswa SMA pada Pembelajaran Daring di Masa Pandemi Covid-19. IQ (Ilmu Al-Qur'an): Jurnal Pendidikan Islam. https://doi.org/10.37542/iq.v3i01.57

Corinna, D. F., Rembulan, I., Hendra, F., Sisingamangaraja, J., Baru, K., \& Selatan, J. (2020). PROBLEMATIKA PEMBELAJARAN BAHASA ARAB SECARA DARING : STUDI KASUS MAHASISWA PROGRAM STUDI BAHASA DAN KEBUDAYAAN ARAB UNIVERSITAS AL-AZHAR INDONESIA. 569-578.

Dalyono. (2015). Psikologi Pendidikan. Rineka Cipta.

Gikas, J., \& Grant, M. M. (2013). Mobile computing devices in higher education: Student perspectives on learning with cellphones, smartphones \& social media. Internet and Higher Education. https://doi.org/10.1016/j.iheduc.2013.06.002

Handarini, O. I., \& Wulandari, S. S. (2020). Pembelajaran Daring Sebagai Upaya Study From Home (SFH) Selama Pandemi Covid 19. Jurnal Pendidikan Administrasi Perkantoran (JPAP).

Isman, M. (2017). Pembelajaran Moda dalam Jaringan (Moda Daring). The Progressive and Fun Education Seminar.

Kumar, V., \& Nanda, P. (2019). Social media in higher education: A framework for continuous engagement. International Journal of Information and Communication Technology Education, 15(1), 109-120. https://doi.org/10.4018/IJICTE.2019010108

Malyana, A. (2020). Pelaksanaan Pembelajaran Daring dan Luring Dengan Metode Bimbingan Berkelanjutan Pada Guru Sekolah Dasar Di Teluk Betung Utara Bandar Lampung. Jurnal Ilmiah Pendidikan Dasar Indonesia, 2(1), 67-76.

Mulyadi. (2010). Diagnosis Kesulitan Belajar \& Bimbingan Terhadap Kesulitan Belajar Khusus. Nuha Litera.

Nafrin, I. A. (2021). EDUKATIF : JURNAL ILMU PENDIDIKAN Perkembangan Pendidikan Indonesia di Masa Pandemi Covid-19 Abstrak. 3(2), 456-462.

Suni Astini, N. K. (2020). Tantangan Dan Peluang Pemanfaatan Teknologi Informasi Dalam Pembelajaran Online Masa Covid-19. Cetta: Jurnal Ilmu Pendidikan, 3(2), 241-255. https://doi.org/10.37329/cetta.v3i2.452

Turmuzi, M., \& Dasing, A. S. H. (2021). EDUKATIF : JURNAL ILMU PENDIDIKAN Analisis Kesulitan Belajar Mahasiswa Secara Online ( E-Learning ) Selama Masa Pandemi Covid-19. 3(3), 900-910.

Zainal Arifin. (2012). Penelitian Pendidikan. Remaja Rosdakarya. 